\title{
DISPERSION MODELING OF NITROUS OXIDE EMISSIONS FROM A NITRIC ACID PLANT IN DEVNYA REGION, BULGARIA
}

\author{
Maya Stefanova $^{1}$, Rozalina Chuturkova $^{2}$, Evgeni Sokolovski $^{3}$, Nina Ilieva $^{4}$ \\ ${ }^{l}$ PhD Student, Department of Ecology and Environmental Protection, Technical University, Varna, Bulgaria \\ ${ }^{2}$ Associate Professor, Department of Ecology and Environmental Protection, Technical University, Varna, Bulgaria \\ ${ }^{3}$ Chief Assistant Professor, Department of Engineering Ecology, University of Chemical Technology and Metallurgy, \\ Sofia, Bulgaria \\ ${ }^{4}$ Chief Assistant Professor, Department of Engineering Ecology, University of Chemical Technology and Metallurgy, \\ Sofia, Bulgaria
}

\begin{abstract}
Within the present research a mathematical modeling is done in order to study the dispersion of nitrous oxide emissions from a single organized source - a nitric acid plant with 363000 tons per year production capacity in the industrial region of Devnya, Bulgaria. Separate simulations are done for the dispersion of $\mathrm{N}_{2} \mathrm{O}$ emissions without any emission reduction measures being implemented in the plant and for $\mathrm{N}_{2} \mathrm{O}$ emission dispersion with a secondary $\mathrm{N}_{2} \mathrm{O}$ decomposing catalyst being installed under different meteorological conditions. Results indicate that a significant decrease of $\mathrm{N}_{2} \mathrm{O}$ concentration in the ground atmospheric layer is achieved after the implementation of the secondary decomposing catalyst - over $81 \%$ reduction of the hourly average $\mathrm{N}_{2} \mathrm{O}$ concentration and up to 80 $\%$ reduction of the annual average $\mathrm{N}_{2} \mathrm{O}$ concentration is calculated. Dispersion models also indicate that the territorial dispersion of $\mathrm{N}_{2} \mathrm{O}$ emissions is reduced as well - the area with $\mathrm{N}_{2} \mathrm{O}$ concentration below $200 \mu \mathrm{g} / \mathrm{m}^{3}$ is 15 times smaller with a secondary $\mathrm{N}_{2} \mathrm{O}$ decomposing catalyst being installed. Research results provide a tool to assess the decomposing catalyst reduction potential and to predict the impact of $\mathrm{N}_{2} \mathrm{O}$ emissions upon the ambient air quality in the source region. Research results prove that high temperature catalytic reduction of $\mathrm{N}_{2} \mathrm{O}$ emissions from nitric acid production by installing secondary decomposing catalyst is an effective method for $\mathrm{N}_{2} \mathrm{O}$ emission reduction and a tool to combat global warming effect.
\end{abstract}

Keywords: ambient air quality, air dispersion modeling, greenhouse gas, nitrous oxide, catalytic emission reduction

\section{INTRODUCTION}

Nitrous oxide $\mathrm{N}_{2} \mathrm{O}$ is a greenhouse gas under the Kyoto Protocol [1] and one of the main reasons for global warming effect [2-4]. $\mathrm{N}_{2} \mathrm{O}$ emissions from industrial installations for nitric acid production have adverse effect upon the ambient air quality in the surrounding area. The effect level depends on the specific topographic and climate conditions of the source region which also affect the dispersion of the pollutant in the ground atmospheric layer and the processes of photo dissociation, chemical destruction and diffusion $[5,6]$. Different measures and techniques for $\mathrm{N}_{2} \mathrm{O}$ emission reduction are developed and applied in nitric acid production plants around the world [7-9]. Installing a non-platinum secondary catalyst that is decomposing $\mathrm{N}_{2} \mathrm{O}$ to nitrogen and oxygen right after its formation in the ammonia burner is a secondary measure that provides $73 \%$ reduction of $\mathrm{N}_{2} \mathrm{O}$ emissions [10]. The achieved $\mathrm{N}_{2} \mathrm{O}$ reduction level has a positive effect upon the ambient air quality in the industrial source surrounding area and is a tool to prevent adverse changes of the global climate system. ****

The present research aim is to study the dispersion of $\mathrm{N}_{2} \mathrm{O}$ emissions from a nitric acid plant with and without a secondary decomposing catalyst being installed and to assess their impact upon the ambient air quality in the surrounding area having in mind the specific topographic and meteorological conditions of the region.

\section{MATERIAL AND METHODS}

Within the present research a mathematical modeling is done along with a software simulation of the dispersion of $\mathrm{N}_{2} \mathrm{O}$ emissions from a single fixed source - a nitric acid plant with 363000 tons per year production capacity in the industrial area of Devnya, Bulgaria. A secondary decomposing catalyst for $\mathrm{N}_{2} \mathrm{O}$ emission reduction has been installed in the plant in September 2005 [10]. According to the European Environment Agency currently there is no specific software product developed for mathematical modeling of $\mathrm{N}_{2} \mathrm{O}$ emission dispersion due to the fact that $\mathrm{N}_{2} \mathrm{O}$ is inert in the troposphere [11-17] and thus all dispersion models for emissions from area, transport or point sources in urban regions can not be applied $[18,19]$. Within this research a practically approbated software product BREEZE AERMOD is used for emission 
dispersion modeling taking into account the topography of the region. In order to ensure maximum reliability of the meteorological conditions of the region validated data is used in the form of hourly meteorological file containing information on 6 parameters - wind speed and direction, ambient air temperature, relative humidity, atmospheric pressure, sun radiation intensity. Research period starts in 2005 , due to the fact that before that year there aren't $\mathrm{N}_{2} \mathrm{O}$ emission reduction measures applied in the nitric acid plant, and ends in 2012.

In order to avoid obtaining of wrong results due to variation of the meteorological conditions $\mathrm{N}_{2} \mathrm{O}$ emission dispersion modeling is done over two main scenarios. The first scenario presents $\mathrm{N}_{2} \mathrm{O}$ emission dispersion with no $\mathrm{N}_{2} \mathrm{O}$ reduction measures being applied in the nitric acid plant. The other scenario presents $\mathrm{N}_{2} \mathrm{O}$ emission dispersion with a secondary $\mathrm{N}_{2} \mathrm{O}$ decomposing catalyst being installed in the plant. Emission dispersion with no $\mathrm{N}_{2} \mathrm{O}$ reduction measures being applied is simulated using data from a single $\mathrm{N}_{2} \mathrm{O}$ emission measurement in 2005 before the implementation of the secondary catalyst and meteorological data for 2005 and 2012. Emission dispersion with a secondary $\mathrm{N}_{2} \mathrm{O}$ decomposing catalyst being installed is simulated using emission data in the form of hourly $\mathrm{N}_{2} \mathrm{O}$ concentration file for 2012 and meteorological data for 2005 and 2012. For every of the four simulations hourly average and annual average $\mathrm{N}_{2} \mathrm{O}$ concentration in the ground atmospheric layer are calculated referring to European and national standards for determination of hourly average and annual average limit values for the content of oxides of nitrogen in the ambient air [20, 21].

\section{RESULTS AND DISCUSSION}

\subsection{Topographic Characteristic of the Region}

The nitric acid plant is located in the east industrial area of Devnya, Bulgaria. The terrain is mostly lowland with some hilly areas and the elevation varies between 0 and $300 \mathrm{~m}$. The highest point in the $5 \mathrm{~km}$ radius area is to the north-northwest from the source. To the south, where Beloslav Lake is situated, the terrain is flat. The nearest settlement is Povelyanovo, a suburb of Devnya (to the north). Other settlements in the area are Razdelna, Beloslav and Strashimirovo with elevation almost equal to the elevation of the source site. Settlements to the north from the source such as Slanchevo (elev. $145 \mathrm{~m}$ ), Kipra (elev. $135 \mathrm{~m}$ ) and Banovo (elev. $340 \mathrm{~m}$ ) can be affected by the emission dispersion. These settlements are situated in hilly areas where displacement is higher or almost equal to the geometric height of the source and for that reason certain meteorological conditions may cause increased pollutant concentrations in the ambient air. Fig-1 presents a topographic map of the source region.

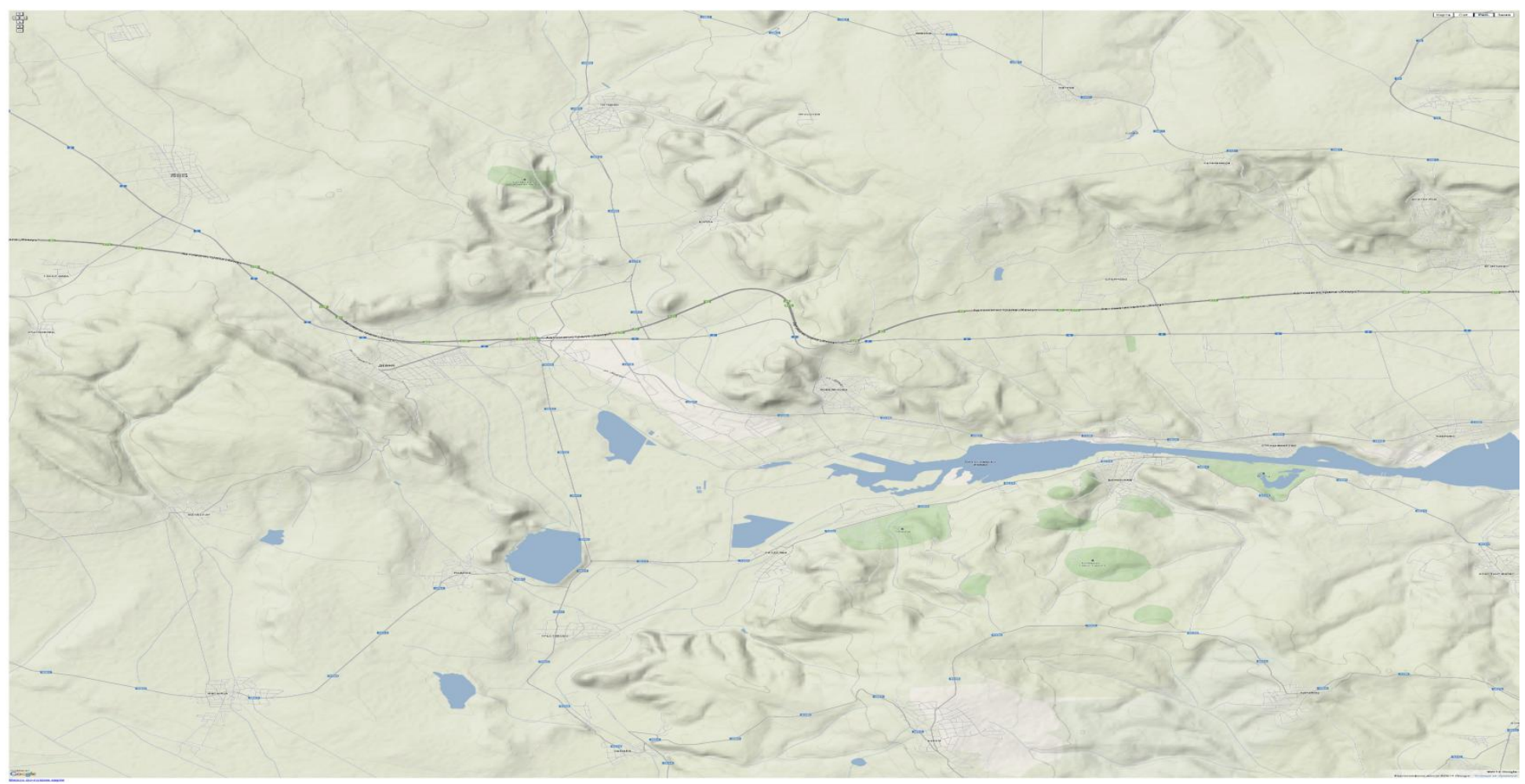

Fig-1: Topographic map of the source region 


\subsection{Climate and Meteorological Conditions of the}

\section{Region}

The climate of the source region is typical for its long and dry summer with high coefficient of windless periods and small rainfall quantity. Winter period is short and relatively soft with greater percentage and quantity of rainfall than summer period. There are breeze currents with east - west direction circulating along Varna Lake and Beloslav Lake. At day time breeze currents come from east while at night they come from west. Moderate winds are typical for the region. The terrain

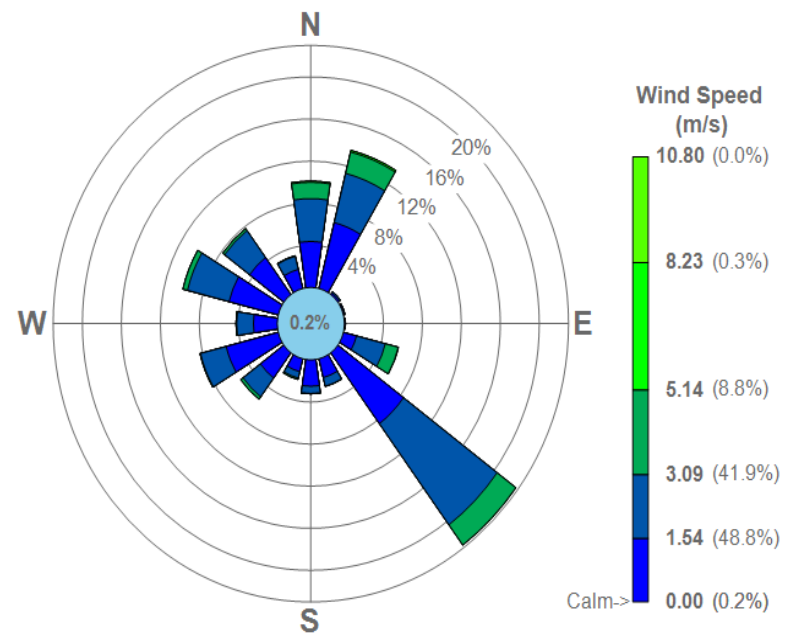

Fig-2: Wind rose for 2005

\subsection{Results}

Within the present research a single organized source of $\mathrm{N}_{2} \mathrm{O}$ emissions is studied - P1 stack at the nitric acid plant. The height of the stack is $130 \mathrm{~m}$ and the diameter is $1.44 \mathrm{~m}$. Due to the fact that $\mathrm{N}_{2} \mathrm{O}$ is inert in the troposphere and emissions are expected to expand on long distance from the source the study area is determined with the following proportions $-20000 \mathrm{~m}$ on west - east direction and $10000 \mathrm{~m}$ on south - north direction. The density of the recipients with a certain $\mathrm{N}_{2} \mathrm{O}$ concentration is 41 recipients on $\mathrm{x}$ (east) and 21 recipients on $\mathrm{y}$ (north) with $500 \mathrm{~m}$ step or the total amount of the recipients is 861 . advantages the formation of inversion fog and considerable pollution of the ambient air. Statistical data indicates that about $60 \%$ of calendar days are foggy.

Fig-2 and Fig-3 present wind roses built for the source region for 2005 and 2012. Both figures indicate that most winds come from southeast with speed varying from 1.54 to 3.09 $\mathrm{m} / \mathrm{s}$. Winds with speed over $5.14 \mathrm{~m} / \mathrm{s}$ are very unusual and mostly come from north-northeast. The percentage of windless periods is very low.

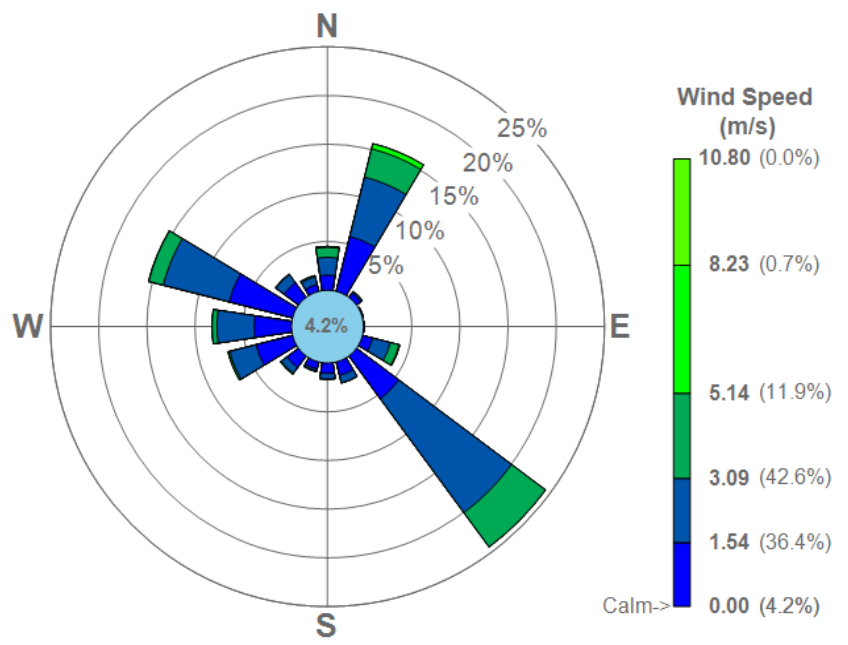

Fig-3: Wind rose for 2012

Using BREEZE AERMOD software a simulation of $\mathrm{N}_{2} \mathrm{O}$ emission dispersion is done. Hourly average and annual average $\mathrm{N}_{2} \mathrm{O}$ concentration in the ground atmospheric layer are calculated.

Table-1 indicates calculation results for peak values of hourly average $\mathrm{N}_{2} \mathrm{O}$ concentration, recipients' coordinates and elevation and date/time when peak values are obtained.

Table-1: Peak values of hourly average N2O concentration $\left(\mu \mathrm{g} / \mathrm{m}^{3}\right)$

\begin{tabular}{|c|c|c|c|c|c|c|c|c|c|c|c|}
\hline \multirow{2}{*}{$\begin{array}{l}\text { Avg } \\
\text { Per. }\end{array}$} & \multirow{2}{*}{$\begin{array}{l}\text { Hig } \\
\text { h }\end{array}$} & \multirow{2}{*}{ Type } & \multirow{2}{*}{ Val } & \multirow{2}{*}{$\begin{array}{l}\text { Date } \\
\text { YYMMDD } \\
\text { HH }\end{array}$} & \multicolumn{2}{|l|}{ UTM } & \multirow{2}{*}{$\begin{array}{l}\text { Elev. } \\
\text { (m) }\end{array}$} & \multirow{2}{*}{$\begin{array}{l}\text { Hil } \\
\text { l } \\
\text { Ht. } \\
\text { (m) }\end{array}$} & \multirow{2}{*}{$\begin{array}{l}\text { Flag } \\
\text { Ht. } \\
\text { (m) }\end{array}$} & \multirow{2}{*}{$\begin{array}{l}\text { Rec. } \\
\text { Typ } \\
\text { e }\end{array}$} & \multirow{2}{*}{ Grid ID } \\
\hline & & & & & East (m) & North (m) & & & & & \\
\hline
\end{tabular}




\begin{tabular}{|c|c|c|c|c|c|c|c|c|c|c|c|}
\hline $1 \mathrm{HR}$ & $1 \mathrm{ST}$ & $\begin{array}{l}\text { Avg. } \\
\text { Conc. }\end{array}$ & 301.96247 & $5 / 09 / 17 / 18$ & $\begin{array}{l}553291.9 \\
5\end{array}$ & 4783610.56 & 0 & 0 & 2 & GC & R0G02000 \\
\hline \multicolumn{12}{|c|}{ Simulation without secondary catalyst being installed and meteorological data for 2012} \\
\hline $1 \mathrm{HR}$ & $1 \mathrm{ST}$ & $\begin{array}{l}\text { Avg. } \\
\text { Conc. }\end{array}$ & 16705.48516 & $12 / 10 / 28 / 01$ & 553785.9 & 4784607.48 & \begin{tabular}{|l|}
155. \\
1
\end{tabular} & 209 & 2 & GC & MN101000 \\
\hline \multicolumn{12}{|c|}{ Simulation with secondary catalyst being installed and meteorological data for 2005} \\
\hline $1 \mathrm{HR}$ & $1 \mathrm{ST}$ & $\begin{array}{l}\text { Avg. } \\
\text { Conc. }\end{array}$ & 117.69145 & $5 / 01 / 19 / 10$ & $\begin{array}{l}554791.9 \\
5\end{array}$ & 4783610.56 & 0 & 0 & 2 & GC & R0G02000 \\
\hline \multicolumn{12}{|c|}{ Simulation with secondary catalyst being installed and meteorological data for 2012} \\
\hline $1 \mathrm{HR}$ & $1 \mathrm{ST}$ & $\begin{array}{l}\text { Avg. } \\
\text { Conc. }\end{array}$ & 3126.84989 & $12 / 01 / 25 / 05$ & 553785.9 & 4784607.48 & \begin{tabular}{|l|}
155. \\
1 \\
\end{tabular} & 209 & 2 & GC & MN101000 \\
\hline
\end{tabular}

As indicated in Table-1 results show a significant decrease of hourly average $\mathrm{N}_{2} \mathrm{O}$ concentration in the ambient air after the implementation of the secondary decomposing catalyst. Simulation without secondary catalyst being installed and meteorological data for 2005 indicates that the peak value of hourly average $\mathrm{N}_{2} \mathrm{O}$ concentration is $302 \mu \mathrm{g} / \mathrm{m}^{3}$ while simulation with secondary catalyst being installed and meteorological data for the same year indicates hourly average $\mathrm{N}_{2} \mathrm{O}$ concentration of $117.7 \mu \mathrm{g} / \mathrm{m}^{3}$ which is 2.5 times lower. Simulation without secondary catalyst being installed and meteorological data for 2012 indicates that the peak value of hourly average $\mathrm{N}_{2} \mathrm{O}$ concentration is $16705.5 \mu \mathrm{g} / \mathrm{m}^{3}$ while simulation with secondary catalyst being installed and meteorological data for the same year indicates hourly average $\mathrm{N}_{2} \mathrm{O}$ concentration of $3126.8 \mu \mathrm{g} / \mathrm{m}^{3}$ which means $81 \%$ reduction of $\mathrm{N}_{2} \mathrm{O}$ level in the ambient air. Specific meteorological conditions in 2012 (e.g. ambient air temperature, atmospheric stability class determined by the mixing height, sun radiation, etc.) need to be emphasized leading to higher $\mathrm{N}_{2} \mathrm{O}$ concentrations in the ground atmospheric layer. Simulation with secondary catalyst being installed and meteorological data for 2012 indicates that the peak value of hourly average $\mathrm{N}_{2} \mathrm{O}$ concentration in the ground atmospheric layer is 10 times higher than the peak value of the simulation without secondary catalyst being installed and meteorological data for 2005. This proves the necessity of modeling 4 simulations for every combination of meteorological data and process conditions.

Figures $4-7$ present contours of hourly average $\mathrm{N}_{2} \mathrm{O}$ concentration $\left(\mu \mathrm{g} / \mathrm{m}^{3}\right)$ in the ground atmospheric layer for every simulation.

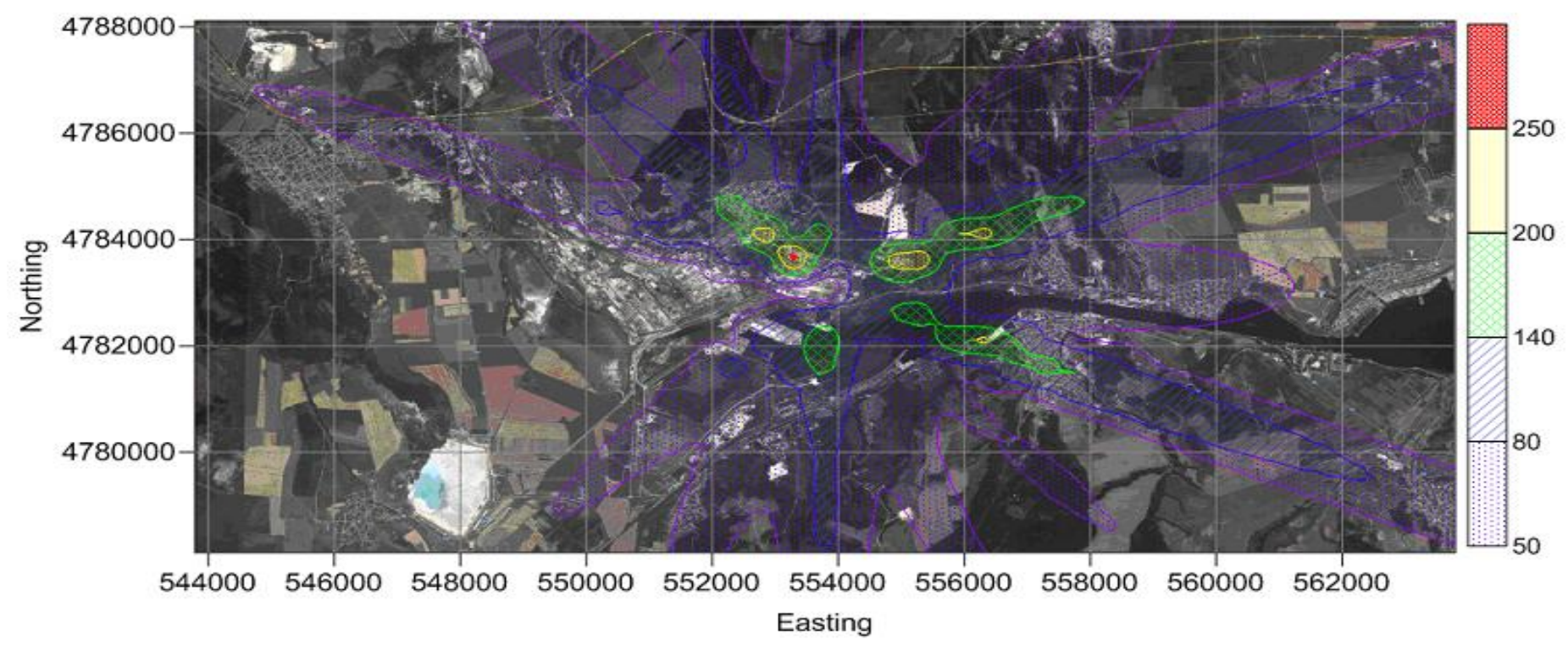

Fig -4: Hourly average $\mathrm{N}_{2} \mathrm{O}$ concentration $\left(\mu \mathrm{g} / \mathrm{m}^{3}\right)$ without secondary catalyst being installed and meteorological data for 2005 


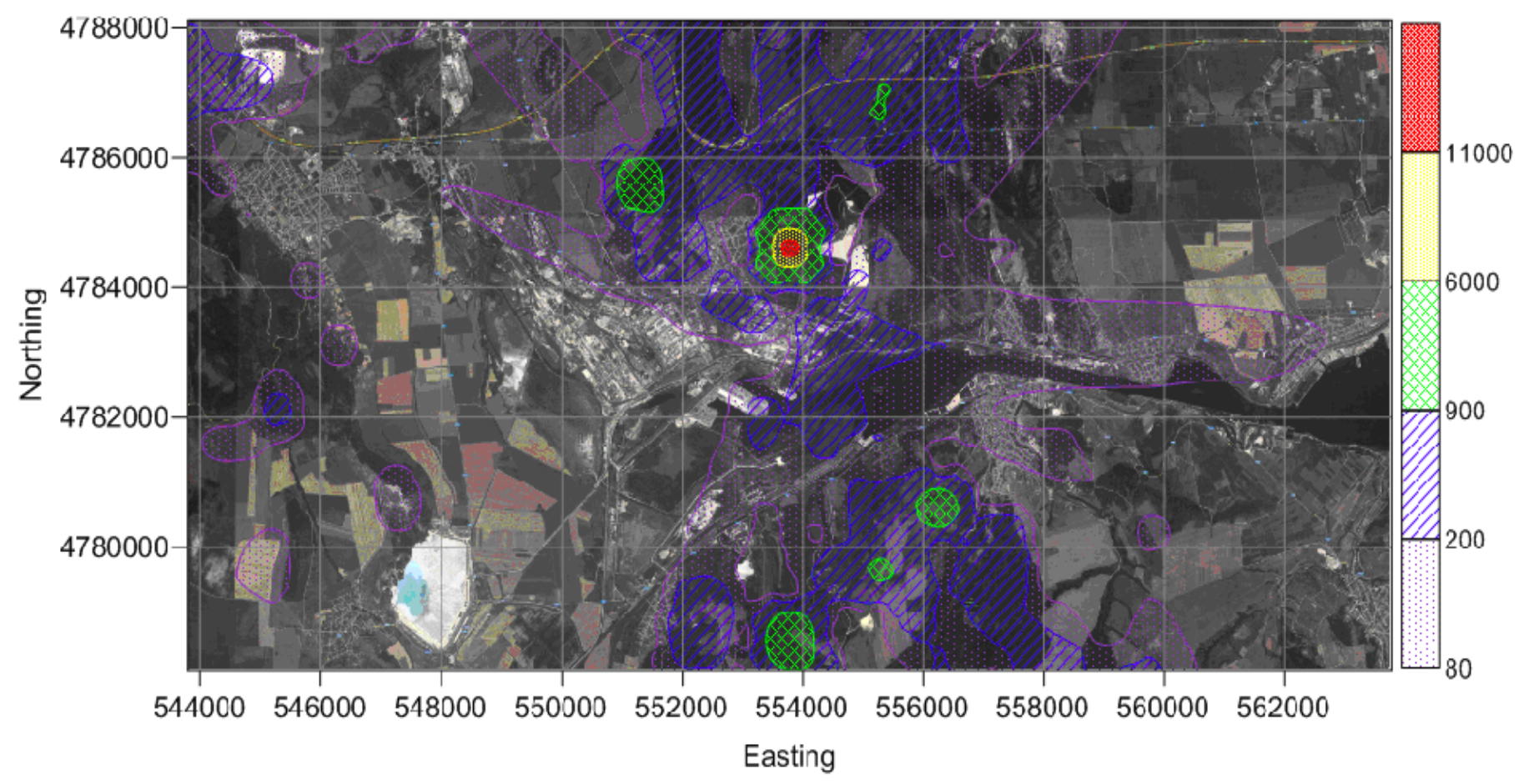

Fig -5: Hourly average $\mathrm{N}_{2} \mathrm{O}$ concentration $\left(\mu \mathrm{g} / \mathrm{m}^{3}\right)$ without secondary catalyst being installed and meteorological data for 2012

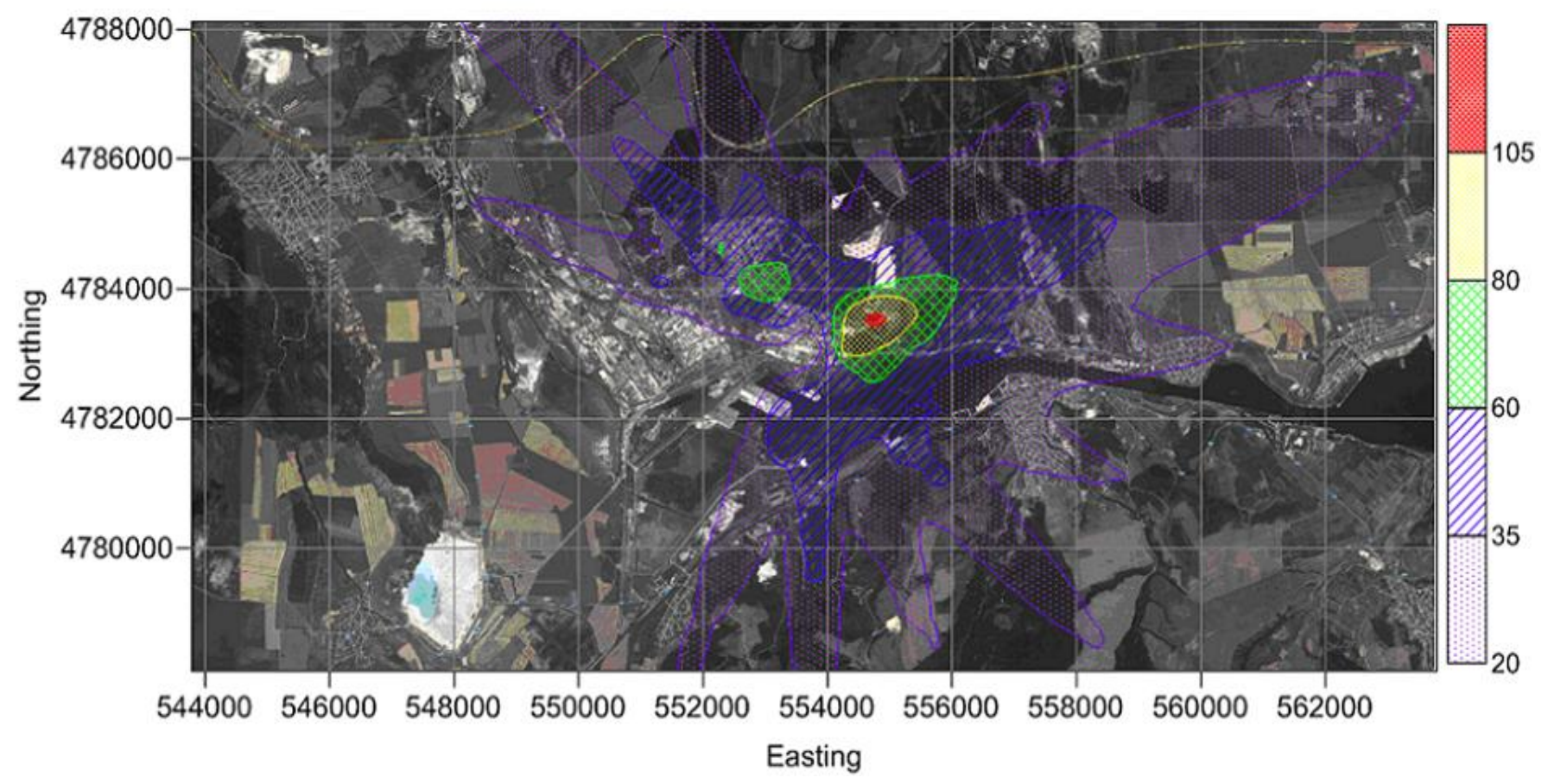

Fig-6: Hourly average $\mathrm{N}_{2} \mathrm{O}$ concentration $\left(\mu \mathrm{g} / \mathrm{m}^{3}\right)$ with secondary catalyst being installed and meteorological data for 2005 


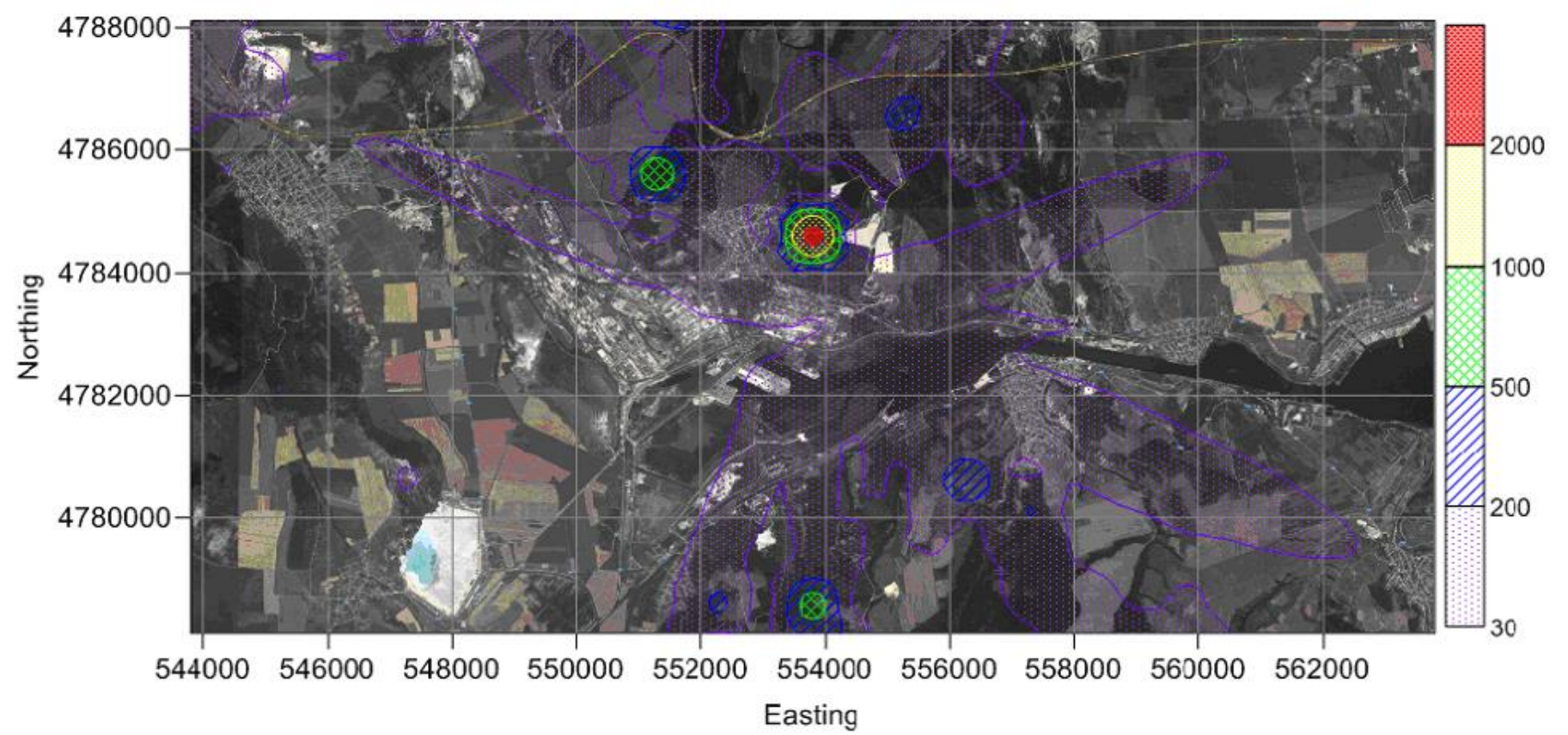

Fig-7: Hourly average $\mathrm{N}_{2} \mathrm{O}$ concentration $\left(\mu \mathrm{g} / \mathrm{m}^{3}\right)$ with secondary catalyst being installed and meteorological data for 2012

The peak value of hourly average $\mathrm{N}_{2} \mathrm{O}$ concentration for simulation without secondary catalyst being installed and meteorological data for 2005 is obtained at $18.00 \mathrm{~h}$ on 17 September 2005 with southeast wind blowing with speed 2.53 $\mathrm{m} / \mathrm{s}$ (Table-1 and Fig-4) while the peak value for simulation with secondary catalyst being installed and meteorological data for the same year is obtained in January with westnorthwest wind blowing with speed $0.5 \mathrm{~m} / \mathrm{s}$ (Table-1 and Fig6). Logically the implementation of the secondary decomposing catalyst leads to $61 \%$ decrease of the hourly average $\mathrm{N}_{2} \mathrm{O}$ concentration due to significant $\mathrm{N}_{2} \mathrm{O}$ emission reduction at the nitric acid plant.

Peak values of hourly average $\mathrm{N}_{2} \mathrm{O}$ concentration in the ground atmospheric layer for both simulations with meteorological data for 2012 are obtained with south wind blowing with speed $2 \mathrm{~m} / \mathrm{s}$ - in October for simulation without secondary catalyst being installed (Table-1 and Fig-5) and in
January for simulation with secondary catalyst being installed (Table-1 and Fig-7). Both peak values are registered in the same recipient with higher elevation than the source height. Excluding the impact of the adverse meteorological conditions in 2012 a significant decrease of hourly average $\mathrm{N}_{2} \mathrm{O}$ concentration is calculated - over $81 \%$ reduction for simulation with secondary catalyst being installed compared to simulation without secondary catalyst being installed. Beside $\mathrm{N}_{2} \mathrm{O}$ concentration decrease a significant reduction of $\mathrm{N}_{2} \mathrm{O}$ dispersion area in the atmosphere is observed. As indicated on Fig-5 and Fig-7 the area with hourly average $\mathrm{N}_{2} \mathrm{O}$ concentration below $200 \mu \mathrm{g} / \mathrm{m}^{3}[20,21]$ is $29 \mathrm{~km}^{2}$ for simulation without secondary catalyst being installed and less than $2 \mathrm{~km}^{2}$ for simulation with secondary catalyst being installed.

Peak values of annual average $\mathrm{N}_{2} \mathrm{O}$ concentration and recipients' coordinates and elevation are presented in Table- 2 .

Table-2: Peak values of annual average $\mathrm{N}_{2} \mathrm{O}$ concentration $\left(\mu \mathrm{g} / \mathrm{m}^{3}\right)$

\begin{tabular}{|l|l|l|l|l|l|l|l|l|}
\hline \multirow{2}{*}{ High } & $\begin{array}{l}\text { Avg. } \\
\text { Conc. }\end{array}$ & UTM & Elev. & Hill Ht. & Flag Ht. & $\begin{array}{l}\text { Rec. } \\
\text { Type }\end{array}$ & Grid ID \\
\cline { 2 - 8 } & East $(\mathrm{m})$ & North $(\mathbf{m})$ & $(\mathrm{m})$ & $(\mathrm{m})$ & $(\mathrm{m})$ & \\
\hline
\end{tabular}




\begin{tabular}{|l|l|l|l|l|l|l|l|l|}
\hline \multicolumn{7}{|l|}{ Simulation without secondary catalyst being installed and meteorological data for 2012} \\
\hline 1ST & $\mathbf{4 8 . 3 7 1 4 9}$ & 551285.9 & 4785607.48 & 157.2 & 260 & 2 & GC & MN101000 \\
\hline Simulation with secondary catalyst being installed and meteorological data for $\mathbf{2 0 0 5}$ \\
\hline 1 ST & $\mathbf{2 . 1 1 1 1 3}$ & 553291.95 & 4783610.56 & 0 & 0 & 2 & GC & R0G02000 \\
\hline Simulation with secondary catalyst being installed and meteorological data for $\mathbf{2 0 1 2}$ & GC & MN101000 \\
\hline 1ST & $\mathbf{9 . 5 7 5 1 2}$ & 551285.9 & 4785607.48 & 157.2 & 260 & 2 & GC \\
\hline
\end{tabular}

Results in Table-2 indicate that annual average $\mathrm{N}_{2} \mathrm{O}$ concentration in the ground atmospheric layer is over 8.9 $\mu \mathrm{g} / \mathrm{m}^{3}$ for simulation without secondary catalyst being installed and meteorological data for 2005 and $2.1 \mu \mathrm{g} / \mathrm{m}^{3}$ for simulation with secondary catalyst being installed and meteorological data for the same year which is over 4 times lower. For simulation with secondary catalyst being installed and meteorological data for 2012 annual average $\mathrm{N}_{2} \mathrm{O}$ concentration is $9.6 \mu \mathrm{g} / \mathrm{m}^{3}$ which is over 5 times lower than the peak value for simulation without secondary catalyst being installed and meteorological data for the same year.
Comparison between simulations with and without secondary catalyst being installed and meteorological data for 2005 indicates that $76.4 \%$ reduction of annual average $\mathrm{N}_{2} \mathrm{O}$ concentration has been achieved. Comparison between both simulations with meteorological data for 2012 indicates 80.2 $\%$ reduction of annual average $\mathrm{N}_{2} \mathrm{O}$ concentration.

Figures 8 - 11 present contours of annual average $\mathrm{N}_{2} \mathrm{O}$ concentration $\left(\mu \mathrm{g} / \mathrm{m}^{3}\right)$ in the ground atmospheric layer for every simulation

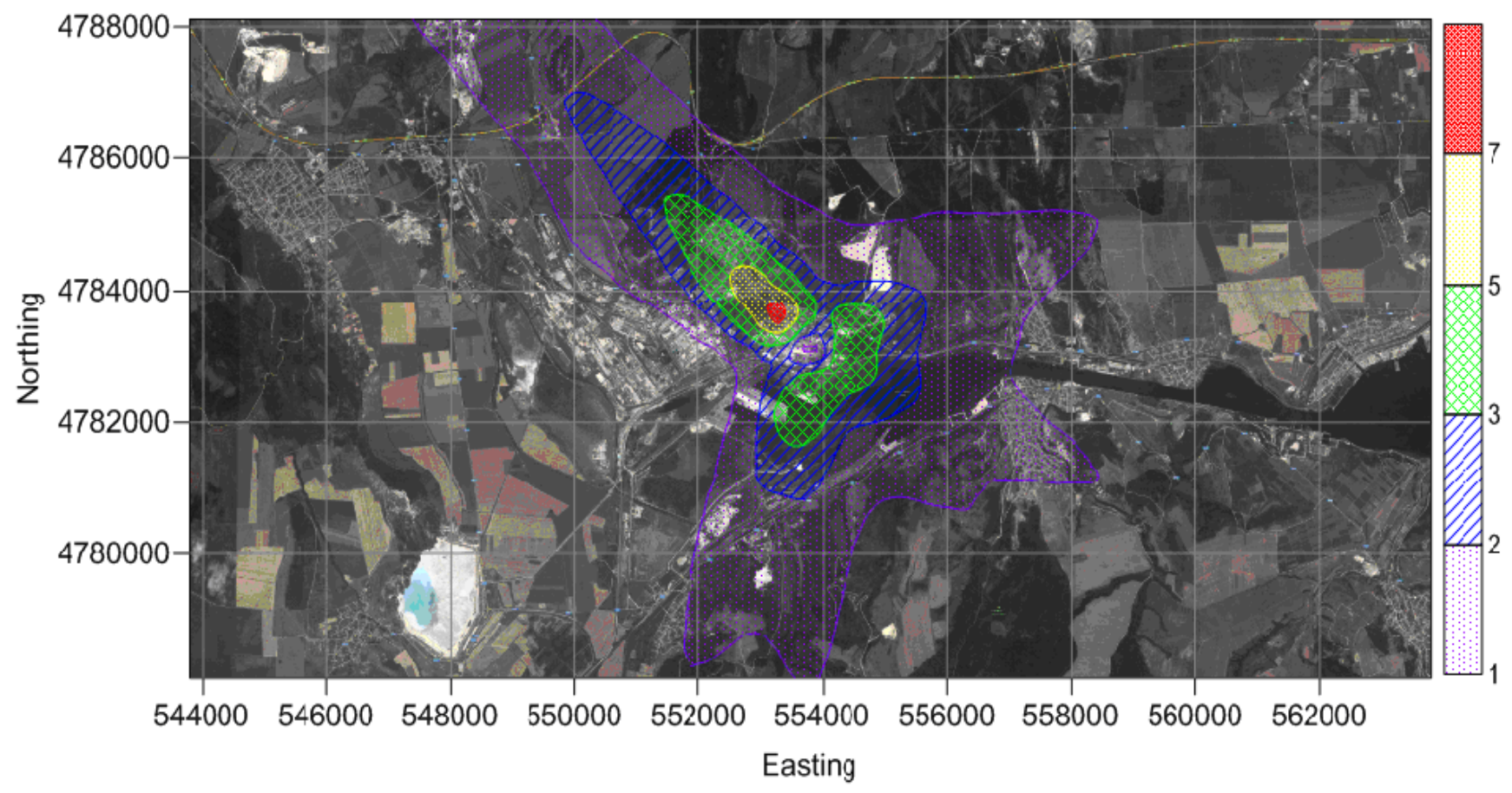

Fig-8: Annual average $\mathrm{N}_{2} \mathrm{O}$ concentration $\left(\mu \mathrm{g} / \mathrm{m}^{3}\right)$ without secondary catalyst being installed and meteorological data for 2005 


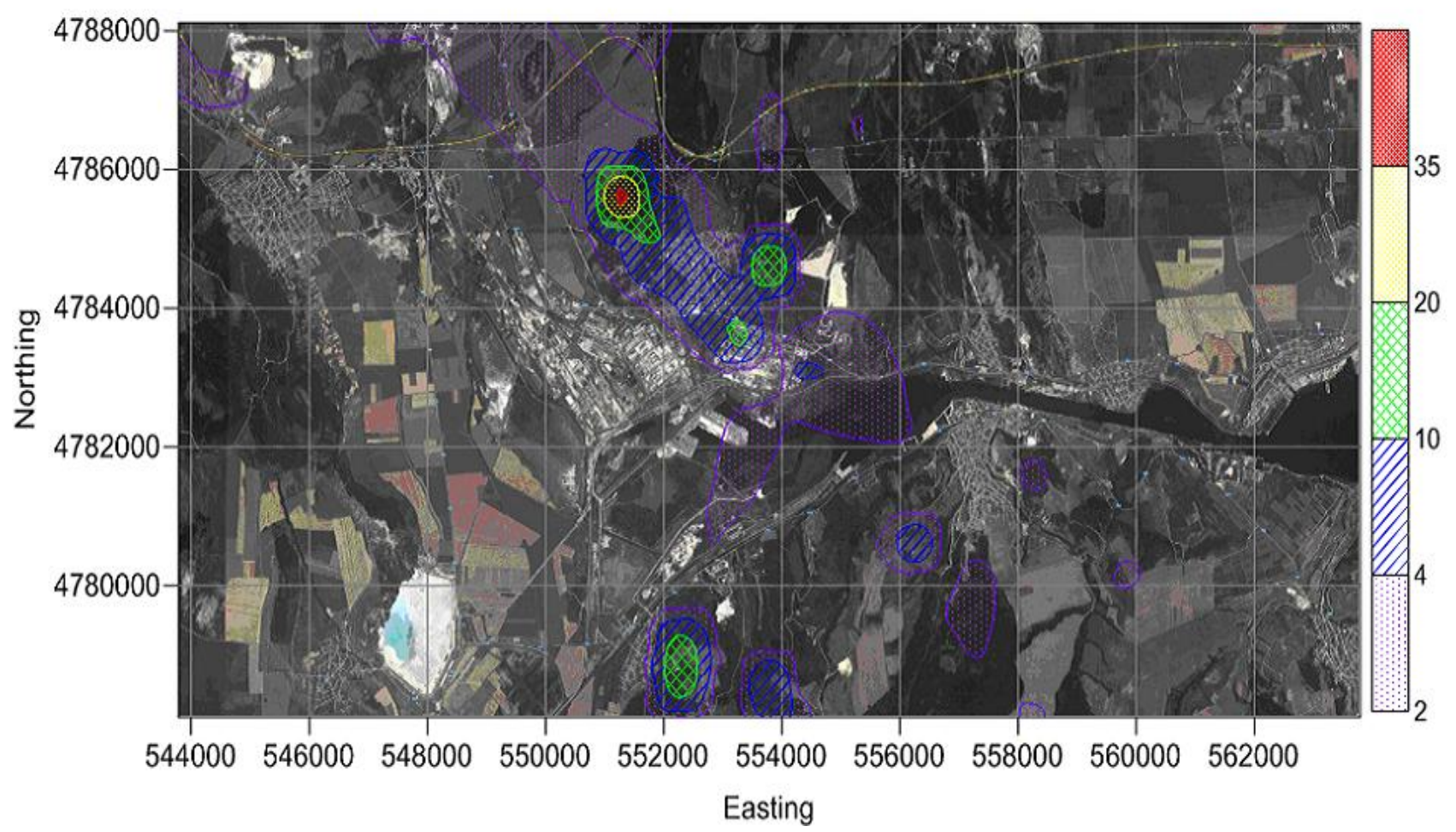

Fig-9: Annual average $\mathrm{N}_{2} \mathrm{O}$ concentration $\left(\mu \mathrm{g} / \mathrm{m}^{3}\right)$ without secondary catalyst being installed and meteorological data for 2012

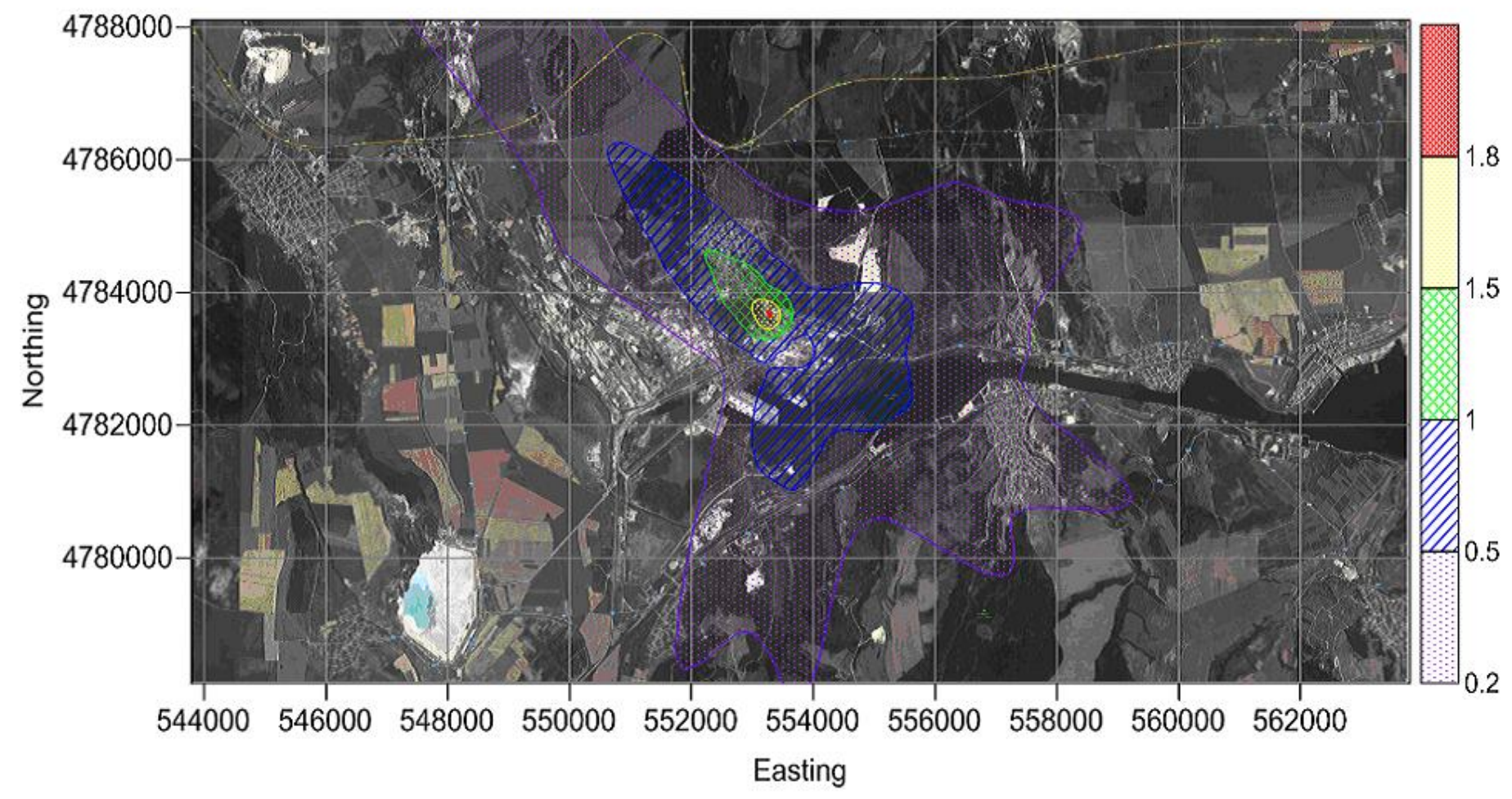

Fig-10: Annual average $\mathrm{N}_{2} \mathrm{O}$ concentration $\left(\mu \mathrm{g} / \mathrm{m}^{3}\right)$ with secondary catalyst being installed and meteorological data for 2005 


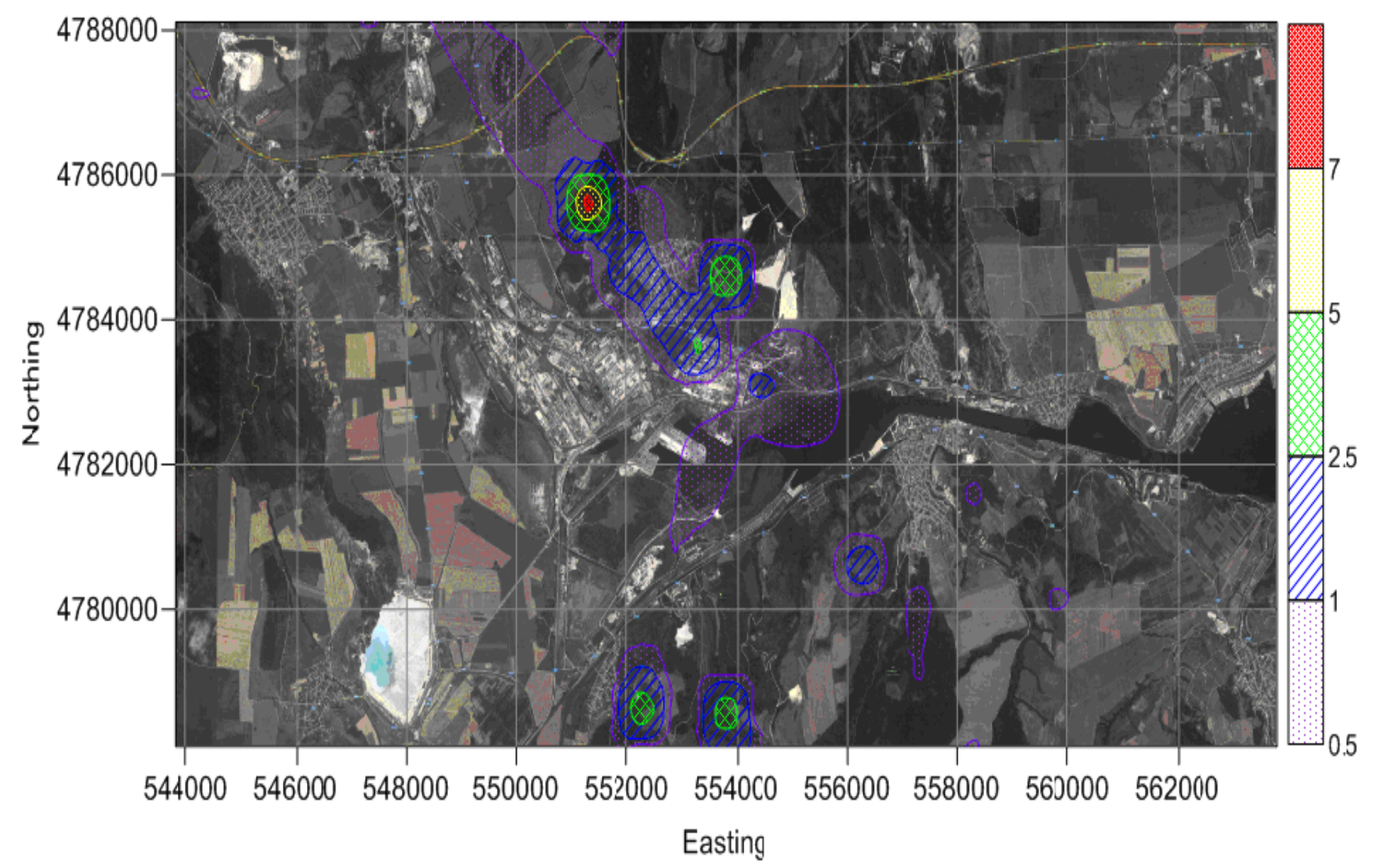

Fig-11: Annual average $\mathrm{N}_{2} \mathrm{O}$ concentration $\left(\mu \mathrm{g} / \mathrm{m}^{3}\right)$ with secondary catalyst being installed and meteorological data for 2012

As indicated on Figures $8-11$ annual average $\mathrm{N}_{2} \mathrm{O}$ concentration in the ground atmospheric layer depends strongly on the meteorological conditions of the region. Adverse meteorological conditions in 2012 affect the dispersion of $\mathrm{N}_{2} \mathrm{O}$ emissions thus causing 4 times higher annual average $\mathrm{N}_{2} \mathrm{O}$ concentrations than peak values calculated for simulations with meteorological data for 2005 . Although meteorological conditions have considerable influence upon $\mathrm{N}_{2} \mathrm{O}$ emission dispersion a significant decrease of annual average $\mathrm{N}_{2} \mathrm{O}$ concentration is registered after the implementation of the secondary decomposing catalyst in the nitric acid plant. By analogy with the results obtained for hourly average $\mathrm{N}_{2} \mathrm{O}$ concentration modeling annual average $\mathrm{N}_{2} \mathrm{O}$ concentration in the atmosphere proves significant decrease of $\mathrm{N}_{2} \mathrm{O}$ emission dispersion area. As presented on Fig-8 and Fig-10 the area with annual average $\mathrm{N}_{2} \mathrm{O}$ concentration below $2 \mu \mathrm{g} / \mathrm{m}^{3}$ is over $20 \mathrm{~km}^{2}$ for simulation without secondary catalyst being installed while for simulation with secondary catalyst being installed $\mathrm{N}_{2} \mathrm{O}$ concentration below $2 \mu \mathrm{g} / \mathrm{m}^{3}$ is registered on a small area directly next to the emission source.

\section{CONCLUSIONS}

Research results indicate a significant decrease of $\mathrm{N}_{2} \mathrm{O}$ concentration in the ground atmospheric layer after the implementation of the secondary decomposing catalyst in the nitric acid plant $-71 \%$ average reduction of hourly average $\mathrm{N}_{2} \mathrm{O}$ concentration and $78 \%$ average reduction of annual average $\mathrm{N}_{2} \mathrm{O}$ concentration for all the simulations done. Beside the reduction of $\mathrm{N}_{2} \mathrm{O}$ concentration a significant decrease of $\mathrm{N}_{2} \mathrm{O}$ emission dispersion area in the ground atmospheric layer is observed. Research results prove the reduction potential of the secondary decomposing catalyst and the positive effect of $\mathrm{N}_{2} \mathrm{O}$ emission reduction upon ambient air quality in the source region. On that basis a conclusion is made that nitric acid plants with similar parameters can be situated directly next to urban areas without causing adverse effect upon ambient air quality having in mind the topography of the region and possible cumulative effect with other air pollutant sources [22]. High temperature catalytic reduction of $\mathrm{N}_{2} \mathrm{O}$ emissions from nitric acid production is proved to be an effective measure for atmospheric $\mathrm{N}_{2} \mathrm{O}$ concentration decrease and a tool to combat adverse changes of global climate system. 


\section{REFERENCES}

[1] The Kyoto Protocol to the United Nations Framework Convention on Climate Change, 1998

[2] Ravishankara A. R., Daniel J. S., Portmann R. W. Nitrous Oxide: The Dominant Ozone-Depleting Substance Emitted in the 21st Century. Science, Vol. 326 (5949), 123, 2009

[3] Petrova D., Kostadinova P., Sokolovski E., Dombalov I. Greenhouse Gases and Environment. Journal of Environmental Protection and Ecology, Vol. 7 (3), 679, 2006

[4] Wuebbles D. J. Nitrous Oxide: No Laughing Matter. Science, Vol. 326 (5949), 56, 2009

[5] Chuturkova R., Stefanova M. Assessment of the Effect of Nitrous Oxide Emissions from Nitric Acid Production upon Ambient Air Quality in Devnya Region. Journal Scientific and Applied Research, Vol. 4, 163, 2013

[6] McElroy M. B., McConnel J. C. Nitrous oxide - a natural source of stratospheric NO. Journal of Atmospheric Sciences, Vol. 28 (6), 1095, 1971

[7] European Comission, Integrated Pollution Prevention and Control. Reference Document on BAT for the manufacture of Large Volume Inorganic Chemicals Ammonia, Acids and Fertilizers, 2007

[8] Agency for Energy and the Environment. Reduction of Nitrous Oxide in the Nitric Acid Industry. The Hague, 2001

[9] Stefanova M. Industrial Methods for Nitrous Oxide Emission Reduction. Ecological Engineering and Environment Protection, Vol. 12 (3-4), 89, 2013 [In Bulgarian]

[10] Stefanova M., Chuturkova R. Nitrous Oxide Catalytic Reduction at a Nitric Acid Plant in Bulgaria. Environ. Prot. Eng., 2014 (in press)

[11] Vallero D. A. Fundamentals of Air Pollution. Academic Press, Burlington, MA, USA, 2007

[12] Tinsley I. J. Chemical Concepts in Pollutant Behavior. Willey, NJ, USA, 2004

[13] Kaur H. Environmental Chemistry. Global Media, Meerut, IND, 2010

[14] Bhagi A. K., Chatwal G. R. Environmental Chemistry. Global Media, Mumbai, IND, 2010

[15] Bailey R. A., Clark H. M., Ferris J. P. Chemistry of the Environment. 2nd edition. Academic Press, San Diego, CA, USA, 2002

[16] Jadhav, H. V., Purohit S. H. Global Pollution and Environmental Monitoring. Global Media, Mumbai, IND, 2008

[17] P. Kudesia V., Ritu Kudesia. Air Pollution. Global Media, Meerut, IND, 2008

[18] Borrego C., Schayes G. Air Pollution Modeling and its Application. Kluwer Academic Publishers, Secaucus, NJ, USA, 2002
[19] Pandurangappa C., Lakshminarayanachari K. Mathematical Model for an Area Source and the Point Source in an Urban Area. International Journal of Research in Engineering and Technology, Vol. 01 (1), 20, 2012

[20] Council Directive 1999/30/EC of 22 April 1999 relating to limit values for sulphur dioxide, nitrogen dioxide and oxides of nitrogen, particular matter and lead in ambient air. OJ L 163, 41, 1999

[21] Regulation № 12 of 15 July 2010 relating to limit values for sulphur dioxide, nitrogen dioxide and oxides of nitrogen, particular matter and lead in ambient air. Governmental newspaper, Vol. 58, 27, 2010

[22] Abdel Salam H. A. Prediction of Pollutants Emission Dispersion of Phosphate Fertilizers Production Facility. International Journal of Research in Engineering and Technology, Vol. 02 (11), 306, 2013 